\title{
Impact of Training and Learning Organization on Employee Competence and Its Implication on Job Satisfaction and Employee Performance of Bank in Indonesia
}

\author{
Achmad Cik \\ \{achmad.cik@civitas.unas.ac.id\}, Nasional University, Jakarta, Indonesia.
}

Muhammad Asdar

\{masdar.ickn@gmail.com\}, Faculty of Economics and Business, Hasanuddin University, Makassar, Indonesia.

\section{Anas Iswanto Anwar}

\{aianwar@fe.unhas.ac.id\},Faculty of Economics and Business,Hasanuddin University, Makassar, Indonesia.

\section{Suryono Efendi}

\{ suryono.efendi@yahoo.com\},Nasional University, Jakarta, Indonesia.

\begin{abstract}
This study aims to analyze: (1) the positive influence of learning organization and training on employee competence; (2) the influence of competence on the job satisfaction; and (3) the positive influence of learning organization, training, competence and job satisfaction on employee performance. The population in this study were employees at the five largest banks in Indonesia which located in South Jakarta. The selected sample of 130 respondents were randomly selected. Using SEM with the AMOS program, the results of this study showed that there is a positive influence of learning and training on employee competence, there is an influences of competence on the job satisfaction, there is a positive influence of learning organization on employee performance, there are no significant influence of training and competence on employee performance, and there is a positive influence of job satisfaction on employee performance.
\end{abstract}

Keywords:

Employee performance, learning organization, training, competence, job satisfaction.

Article Received: 18 October 2020, Revised: 3 November 2020, Accepted: 24 December 2020

\section{Introduction}

In recent years, bankers faced a very rapid development of technology. It has encouraged new players, one of the companies engaged in financial technology (fin-tech), which also entered the business as a bank run. Technological developments have encouraged banks to be transformed following the industrial revolution platform 4.0. According to the Chairman of the Banks Association, Kartika Wirjoatmodjo, the presence of fin-tech and businesses like technology is a challenge for the banking sector in recent years. The banking sector must compete with the technology industry with a rapid transformation. Efforts to respond to these challenges, bankers have to accelerate its business in reaching the clappers to provide an easy and fast access.
The magnitude of the challenges in the banking world driving the transformation and digitization of banking designed to mature with setting up the infrastructure, human resources (HR), up-regulation capable of stakeholders. HRrelated banks are very related to the competence of employees in support of the banking performance. Employee competence certainly influenced by many factors that can impact employee performance. In this research, employee performance will be the focus with the employees of the 5 largest banks in Indonesia as respondents. Performance 5 largest banks in Indonesia dominate market share in Indonesia. Seen from the performance of the bank based on total assets follows. 
Table 1. Performance of the 5 Largest Banks in Indonesia Based on Total Assets

\begin{tabular}{|c|l|c|}
\hline Ranked & \multicolumn{1}{|c|}{ Bank } & Total Assets \\
\hline 1 & PT. Bank Rakyat Indonesia (Persero) & 1.216 .323 .558 \\
\hline 2 & PT. Bank Mandiri (Persero) & 1.035 .916 .523 \\
\hline 3 & PT. Bank Central Asia Tbk & 814.559 .087 \\
\hline 4 & PT. Bank Negara Indonesia (Persero) & 744.421 .643 \\
\hline 5 & PT. Savings Bank Negara (Persero) & 301.346 .488 \\
\hline
\end{tabular}

The fifth largest bank in Indonesia also have to face the challenge to strengthen the digital infrastructure. In the development of digital infrastructure that the banking sector must prepare qualified human resources and able to deal with the digital development trend by continuing to do a thorough education and training. Training is a program that needs to be done to improve the competence of employees. Alainati, et al (2010) states that competence is increasingly important to the success of an organization. The growing need for technology, organizations need to have employees who know how to react, interact and make the right decisions to deal with changing circumstances. In maximizing the competence of each individual, it is important to know the factors that affect competence. One that affects competence is training. Training should be treated and adapted to the needs of the market to maximize the benefits of individual competencies. Training should be done well in order to have a positive effect on employee competency.

In addition, competence is also influenced by the learning organization. Suzan and Marjulin (2016) explains that learning organizations produce competence is a primary characteristic of people who produce effectiveness and workplace excellence. Successful learning organization impact on organizational competence which is a behavioral approach to emotional intelligence, social intelligence and cognitive intelligence.

Learning organization and training not only affect competence, but can encourage employee performance improvement. Nzioka (2012) found that there is a positive relationship between organizational learning and organizational performance. Therefore, improvement of organizational learning can improve organizational performance. Nafei (2015) revealed that the organizational aspects of learning have a significant direct effect on the performance of the organization. Learning organization serves as a catalyst to improve organizational performance and is regarded as one of the most important problems in modern managerial literature (Elnaga dan Imran, 2013).

Learning and training as a factor increasing employee competency encourage employee satisfaction. Margono, et al. (2017) states that job satisfaction has positive influence on employee performance. Reinforced by Bhola (2015) that employee satisfaction is a critical success factor for all organizations. Companies must constantly satisfy the employees in order to remain profitable and meet company objectives.

\section{Literature Review}

\subsection{Employee Performance}

The phenomenon of employee performance is a multidimensional construction and is very important to determine the success or failure of an organization. Employees are the blood flow to the business and is the most valuable asset of any organization because they can make or break an organization, reputation and may affect the profitability of the organization (Sendawula, et al., 2018).

The concept of organizational performance is the company's capacity to achieve the goal of independent efficiently (Venkatraman and Ramanujam, 1986). One of the elements that can be judged from the organization's performance is the performance of employees through the level of their productivity through achievement through indicators such as quality, quantity, knowledge or 
creativity of individuals to the work achieved in accordance with the responsibilities charge during the specified period (Muda, et al., 2014).

\subsection{Job Satisfaction}

Job satisfaction is the level of positive feelings or attitudes held by individuals against employment. When someone says that he has a high job satisfaction, it means that she loved her job, feel good about it and appreciate the dignity of work. In a survey on job satisfaction of bank employees' perspective. Job satisfaction factors, namely salaries of employees, performance appraisal, promotion strategies, employee relations with management and employee relations with other employees, training and development programs, workload and working hours was found necessary to improve the job satisfaction of bank employees in the bank. Increased levels of these factors increase overall employee satisfaction (Kapoor et al,2016).

\subsection{Employees Competence}

Competence is a characteristic of individuals associated with superior performance and a certain flair in practice and application knowledge necessary to do a job (Zaim, et al., 2013). Then, Escrig-Tena and Bou-Llusar (2005) defines competence as a combination of experience, knowledge, and skills possessed by individuals or groups of individuals.

Human resources as a corporate asset that is expected to support the company's performance. Competence is a human resources system to compare one with the other human resources. Through the competence, the company can identify the attitudes, knowledge, abilities, and skills required in a particular job in aligning strategy and priorities of the company (RongRong et al., 2007). Based on the cognitive aspects and aspects of action, competence is defined as the ability and skill of specialized companies in the development of their resources by considering the cognitive characteristics in achieving the goals of the company [13].

\subsection{Training}

Training refers to the planned intervention aimed at improving the job performance of individual elements (Chiaburu and Tekleab, 2005). Training defined as the development of knowledge, skills, and attitudes needed by the employee to perform a task or job adequately or to improve performance in the workplace (Tharenou, et al., 2007). Training and development programs which effectively aims to improve employee performance. Training refers to bridge the gap between current performance and desired performance standards. Training can be provided through different methods such as coaching and mentoring, peer cooperation and participation by subordinates. Work in teams allow employees to participate actively in the work and result in better performance, therefore improving organizational performance. The training program is not only to develop employees but also help organizations to utilize their human resources as well as possible for the sake of gaining a competitive edge. Therefore, it seems mandatory for the company to plan for such a training program for its employees to enhance their capabilities and competencies required in the workplace (Shen and Darby, 2006).

\subsection{Learning Organization}

Learning Organization concept introduced by Senge (2006) published a book entitled The Fifth Discipline. In his book explains that the Learning Organization Practice: (1) organizations implementing learning organization by supplying new ideas and new information. The new ideas and information sourced from the surrounding environment, development of employees and other relevant sources; (2) new knowledge of new ideas and information that should be transferred to all elements of the organization so that all the new information conveyed to all units within the organization; and (3) changes in organizational behavior is a result of the new knowledge received.

The concept of Learning Organization is an organization that proactively create, acquire knowledge, and transfer the knowledge that 
change the behavior of the organization based on new knowledge and new insights [18].

\subsection{Influence Learning Organization Against Employee Competency}

Tanriverdi and Zehir (2006) states that the learning organization is an organization that does a change in mental models to generate learning skills through a healthy mind, the ability to read a comprehensive model, understand interdependence, the ability to create a shared vision, and have the knowledge and capacity of other to share in understanding the technological and economic innovation. Based on research studies that have been done before it can be concluded that affect the learning organization competence, network connections, and others. Successful learning organization impact on organizational competence which is a behavioral approach to emotional intelligence, social intelligence and cognitive intelligence (Suzan and Marjulin, 2016).

\subsection{Influence Against Employee Competency Training}

Shen and Darby (2006) stated that the training program is not only to develop employees but can help an organization to take advantage of the human resources of the organization as well as possible for the sake of gaining a competitive edge. Thus, the company is obliged the company to plan a training program for employees to enhance the capabilities and competence necessary to complete the job.

Farooq and Khan (2011) that the company is not able to achieve higher performance without utilization of human resources best. It can only happen when the company is able to meet the needs of job-related employees in a timely manner. Training is one way to identify the needs of employees who are not and then establish the required level of competence so that they can work well to achieve organizational goals.

Alainati et al., (2010) states that there is a positive relationship between education, training and competence. The implications of the research explained that education and training must be implemented correctly in order to affect competence.

\subsection{The Effect Of Job Satisfaction Competency}

The three predictor variables employee competency positively related to job satisfaction Jeon, et al. (2014). One of the predictors of competence is through training programs that help labor to reduce the anxiety that comes from a job in the workplace (Chen, et al., 2004). The greater the gap between the skills required and owned by workers, the higher the dissatisfaction of workers [23]. Research done by Margono, et al., (2017) found that the competence positive effect on job satisfaction. Strengthened by the findings (Syahrum, et al., 2016) that competence and significant positive effect on job satisfaction.

\subsection{Influence on Employee Performance Learning Organization}

Mbuthia (2018) states that the concept of the learning organization is learning with much broader objectives for the organization's success in a dynamic global economy. Focus on organizational learning raises cognitive approach where trust and insight is seen as a critical influence on the effectiveness of the organization. His research explained that continuous learning, inquiry and dialogue and empowerment of employees are found statistically significant in predicting the performance of a commercial bank. His research concluded that the dimensions of the learning organization has a significant impact on the performance of the organization in the banking sector.

Nzioka (2012) found that there is a positive relationship between organizational learning and organizational performance. Therefore, improvement of organizational learning can improve organizational performance. His research explains that the conversion of knowledge and empowerment affects organizational performance through organizational learning dimension. Penelitinnya have contributed to a better 
understanding of how to promote organizational learning in a commercial bank. His research also contributed to the empirical study of the relationship between organizational learning and performance. Specifically, the main contribution of this research is probably the development model that is confirmed empirically on the relationship between factors of organizational learning, the dimensions of organizational learning and organizational performance.

Nafei (2015) revealed that the organizational aspects of learning have a significant direct effect on the performance of the organization. Learning organization serves as a catalyst to improve organizational performance and is regarded as one of the most important problems in modern managerial literature. Khandekar and Sharma (2006) explains that the learning organization, which largely reflected through HRM has a positive correlation with the performance of the organization.

\subsection{Effect of Training on Employee Performance}

Elnaga and Imran (2013) explains that the achievements of the company depends on employee performance. Therefore, top management realized that the importance of investing in employee training and development for improving the performance of employees. Based on the review of the literature and some case studies on the importance of training to improve workforce performance by understanding the development of employees through training programs and its influence on employee performance and on the basis of a review of the latest evidence of such a relationship, offer advice to top management in the form of checklists, appropriate for all businesses, to assess the performance of employees and to determine the actual cause of performance problems so that the problem can be solved in time through a training program.

\subsection{Effect of Competence on Employee Performance}

Research done by Zaim et al., (2013) reveals that there is a positive relationship between competence and performance of individuals. Furthermore, the core competencies proved to have the most significant effect on the performance of the individual. The study provides some empirical evidence that refers to the individual's competence effects on organizational performance. His findings contain useful information for management practitioners on maintaining and improving the competence of individuals to improve organizational performance. In line with the Rong-rong et al (2007), that the HR competency helps companies to identify the knowledge, skills, attitudes, and skills required in a particular job to align strategies and priorities.

Jabbouri and Zahari (2014) explains that there is a significant correlation between core competencies and organizational performance. Based on this, the research suggests the bank's management to develop core competencies for human resources as a strategic tool to improve organizational performance and extend the empirical knowledge of the banking sector in particular.

Reinforced by Martini, et al.'s research (2018) that the competence and positive effect on employee performance and is supported by the findings found by Syahrum et al. (2016) that the competencies and significant positive effect on employee performance. This relationship eventually contribute to the highest organizational performance.

\subsection{Effect of Job Satisfaction on Employee Performance}

Employee satisfaction is a critical success factor for all organizations. Companies must constantly satisfy the employees in order to remain profitable and meet company objectives. Job satisfaction can be defined as the degree of positive feelings or attitudes held by individuals for their jobs. When someone claimed to have a high work satisfaction indicate that the employees loved her job. Job satisfaction is an important technique that is used 
to motivate employees to work harder [7]. Reinforced by research Margono et al. (2017) that job satisfaction has positive influence on employee performance.

\section{Research Methods}

\subsection{Conceptual Framework}

Conceptual framework used in this study can be seen in figure 1 below.

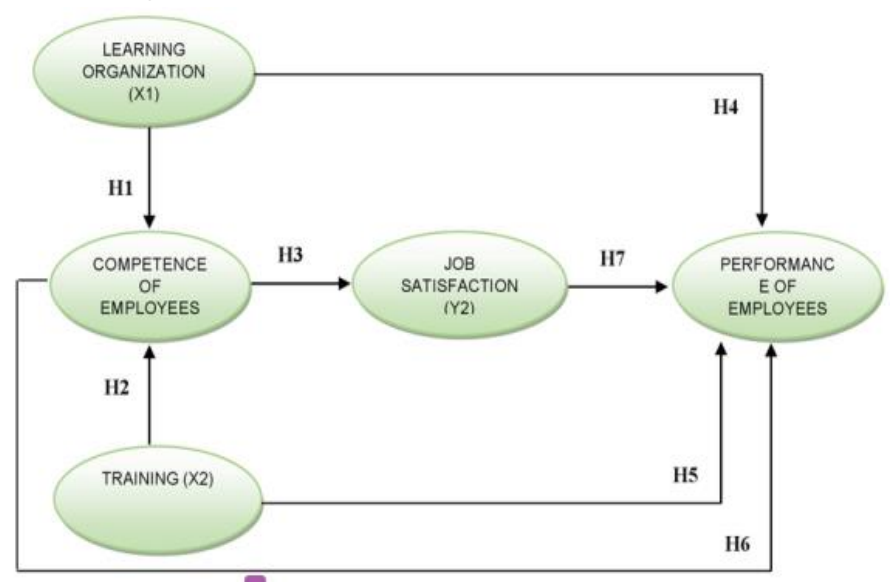

Fig. 1. Conceptual Framework

Based on the conceptual framework above, the hypothesis proposed in this study as follows:

1. Hypothesis 1: There is a positive influence on learning to competence of employees.

2. Hypothesis 2: There is a positive effect of training on employee competency.

3. Hypothesis 3: There is a competence influence on job satisfaction.

4. Hypothesis 4: There is a positive influence on the performance of a learning organization.

5. Hypothesis 5: There is no effect of training on employee performance.

6. Hypothesis 6: There is no competence influence on employee performance.

7. Hypothesis 7: There is a positive effect of job satisfaction on employee performance.

\subsection{Research design}

The analytical method used to answer the hypothesis using SEM with AMOS program.

\subsection{Population and Sample}

The population in this study were employees at the five largest banks in Indonesia which is the location of branch offices located in South Jakarta. The sampling technique in this study using simple random sampling, considering the number of samples scattered and very large. The samples used in this study refers to the opinion Hair, et al. (2010) that the method is widely used in SEM is the maximum likelihood (ML). Recommended sample size is 100-200. Therefore. Referring to these opinions, the respondents in this study amounted to 130 so that the number of samples required in SEM has been fulfilled.

\subsection{Method of Collecting Data}

Distributing questionnaires in this study using a questionnaire that has provided the answer so that respondents can just choose the answers that have been provided. The questionnaire using a Likert scale of 1-5. Likert scale was designed to test how strong the subject agree or disagree with statements on a five-point scale.

\subsection{Variables and Indicators}

The variables and indicators in this study are presented in Table 2 below.

Table 2. Variables and Indicators

\begin{tabular}{|l|l|l|}
\hline \multicolumn{1}{|c|}{ Variables } & \multicolumn{1}{|c|}{ Indicator } & \multicolumn{1}{c|}{ Source } \\
\hline Learning & Continuous learning (X1.1) & \\
Organization (X1) & Team learning (X1.2) & Marsick and Watkins (2003) \\
& Empowerment (X1.3) & \\
& System connection (X1.4) & \\
& Strategic leadership (X1.5) & \multirow{2}{*}{ Sultana, et al. (2012) } \\
\hline Training (X2) & The development of knowledge & \\
& (X2.1) & \\
& Skills (X2.2) & \\
\hline
\end{tabular}




\begin{tabular}{|l|l|l|}
\hline & $\begin{array}{l}\text { Capability (X2.3) } \\
\text { Competence (X2.4) } \\
\text { Behavior (X2.5) }\end{array}$ & \\
\hline Competence (X3) & $\begin{array}{l}\text { Knowledge (X3.1) } \\
\text { Skill (X3.2) } \\
\text { Attitudes (X3.3) } \\
\text { Organizational resource (X3.4) } \\
\text { Capabilities (X3.5) } \\
\text { Personal learning abilities (X3.6) }\end{array}$ & $\begin{array}{l}\text { Ubeda, et al. (2017) } \\
\text { Martini, et al. (2018) } \\
\text { Jabbouri and Zahari (2014) } \\
\text { Wang Chin Hsi-Kong } \\
\text { (2007) }\end{array}$ \\
\hline Job Satisfaction & $\begin{array}{l}\text { Salary / Pay (X4.1) } \\
\text { Promotion (X4.2) } \\
\text { Communication (X4.3) } \\
\text { Performance appraisal system (X4.4) } \\
\text { Contingent reward (X4.5) } \\
\text { Co-workers / employee relationship } \\
\text { with other employee (X4.6) }\end{array}$ & Bhola (2015) \\
\hline Employee & $\begin{array}{l}\text { Task performance (Y1.1) } \\
\text { Situational (Y1.2) } \\
\text { Worformance (Y) } \\
\text { Responsibility (Y1.4) } \\
\text { Cooperation (y1.5) } \\
\text { Initiative (Y1.6) }\end{array}$ & $\begin{array}{l}\text { Martini, et al. (2018) } \\
\text { Wang (2007) }\end{array}$ \\
Aima, et al. (2017) \\
\hline
\end{tabular}

\section{$4 \quad$ Result and Discussion}

\subsection{Data Analysis}

\subsubsection{Evaluation of Univariate Normality}

The evaluation of the normality of the data using criteria skewness critical ratio value equal to \pm 2.58 at the 0.01 level. The results of data processing skewness values obtained cr for each indicator there are no values above 2.58. Thus, all variables meet univariate normality assumption. Thus, the univariate normality met.

\subsubsection{Evaluation of Outlier}

Outlier means unusual. If there are very different observations to other observations it is said to be an outlier observations.Based on the $1 \%$ level of significance was found that all the observations do not have a significance value $<0.001$ there are outliers in the data processing of this research.

\subsubsection{Construct Validity 4.1.3.1 Convergent validity}

Convergent validity become one of the requirements fulfillment unidimensional. Testing the validity of using standardized regression weights and weight Regression. The following values result loading factor regression weights as follows:

Table 3. Convergent Validity

\begin{tabular}{|l|c|c|c|c|c|}
\hline \multicolumn{1}{|c|}{$\begin{array}{c}\text { Latent } \\
\text { Variables }\end{array}$} & Indicator & $\begin{array}{c}\text { Estimate } \\
\text { Loading } \\
\text { Factor }\end{array}$ & $\begin{array}{c}\text { Standardized } \\
\text { Factor Loading }\end{array}$ & $\mathbf{P}$ & Description \\
\hline $\begin{array}{l}\text { Learning } \\
\text { Organization } \\
(\mathrm{X} 1)\end{array}$ & $\mathrm{X} 1.1$ & 1,000 & .710 & $* * *$ & Significant \\
\cline { 2 - 6 } & $\mathrm{X} 1.2$ & 1,310 & 0.875 & $* * *$ & Significant \\
\cline { 2 - 6 } & $\mathrm{X} 1.3$ & 1.279 & 0.886 & $* * *$ & Significant \\
\cline { 2 - 6 } & $\mathrm{X} 1.4$ & 1,153 & .790 & $* * *$ & Significant \\
\cline { 2 - 6 } & $\mathrm{X} 1.5$ & .811 & 0.594 & $* * *$ & Significant \\
\cline { 2 - 6 } & $\mathrm{X} 1.6$ & 1,016 & 0.679 & $* * *$ & Significant \\
\hline Training (X2) & $\mathrm{X} 2.1$ & 0.831 & 0.733 & $* * *$ & Significant \\
\cline { 2 - 6 } & $\mathrm{X} 2.2$ & 0,877 & .913 & $* * *$ & Significant \\
\cline { 2 - 6 } & $\mathrm{X} 2.3$ & 0,753 & 0.742 & $* * *$ & Significant \\
\hline
\end{tabular}




\begin{tabular}{|l|c|c|c|c|l|}
\hline \multirow{4}{*}{$\begin{array}{l}\text { Competence } \\
\text { (X3) }\end{array}$} & $\mathrm{X} 2.4$ & 0.776 & 0.691 & $* * *$ & Significant \\
\cline { 2 - 6 } & $\mathrm{X} 2.5$ & 1,000 & 0.985 & $* * *$ & Significant \\
\cline { 2 - 6 } & $\mathrm{X} 3.1$ & 0.933 & .820 & $* * *$ & Significant \\
\cline { 2 - 6 } & $\mathrm{X} 3.2$ & 1,010 & 0.905 & $* * *$ & Significant \\
\cline { 2 - 6 } & $\mathrm{X} 3.3$ & .976 & 0.847 & $* * *$ & Significant \\
\cline { 2 - 6 } & $\mathrm{X} 3.4$ & .942 & 0,893 & $* * *$ & Significant \\
\cline { 2 - 6 } & $\mathrm{X} 3.5$ & 1.057 & 0.891 & $* * *$ & Significant \\
\cline { 2 - 6 } & $\mathrm{X} 3.6$ & 1,000 & .846 & $* * *$ & Significant \\
\hline \multirow{4}{*}{$\begin{array}{l}\text { Job } \\
\text { (X4) }\end{array}$} & $\mathrm{X} 4.1$ & 0.887 & 0.843 & $* * *$ & Significant \\
\cline { 2 - 6 } & $\mathrm{X} 4.2$ & 0.916 & .834 & $* * *$ & Significant \\
\cline { 2 - 6 } & $\mathrm{X} 4.3$ & 1,036 & 0,885 & $* * *$ & Significant \\
\cline { 2 - 6 } & $\mathrm{X} 4.4$ & 0.967 & .873 & $* * *$ & Significant \\
\cline { 2 - 6 } & $\mathrm{X} 4.5$ & .953 & 0.815 & $* * *$ & Significant \\
\cline { 2 - 6 } & $\mathrm{X} 4.6$ & 1,000 & 0.825 & $* * *$ & Significant \\
\hline Employee & $\mathrm{Y} .1$ & 1,000 & .814 & $* * *$ & Significant \\
\cline { 2 - 6 } Performance & $\mathrm{Y} .2$ & 0,879 & 0.801 & $* * *$ & Significant \\
\cline { 2 - 6 }$(Y)$ & $\mathrm{Y} .3$ & 0,940 & .786 & $* * * *$ & Significant \\
\cline { 2 - 6 } & $\mathrm{Y} .4$ & .807 & .832 & $* * *$ & Significant \\
\cline { 2 - 6 } & $\mathrm{Y} .5$ & 0.739 & .730 & $* * *$ & Significant \\
\cline { 2 - 6 } & $\mathrm{Y} .6$ & 0.676 & .639 & $* * *$ & Significant \\
\hline
\end{tabular}

Table 2 shows that all relationships have a $\mathrm{P}$ value produced is very small ie $<0.001$ marked with 3 asterisks $(* * *)$, thus all the indicators was significant as a measure of their respective latent constructs. Based on the above table it is known that all the indicators have a loading factor greater than 0.50 so that all the indicators meet the convergent validity as a measure of their respective latent constructs.

\subsubsection{Reliability Indicators}

Measuring reliability indicators using Squared Multiple Correlations (SMC) which is the square of the estimated value terstandarisir. SMC value of each variable can be interpreted as an indicator of the reliability indicators. Reliable indicators SMC has a value of $>0.5$. Here Square Multiple Correlations value of each indicator.

Table 4. Squared Multiple Correlations

\begin{tabular}{|l|c|c|}
\hline \multicolumn{1}{|c|}{ Latent variables } & Indicator & SMC \\
\hline Learning Organization & $\mathrm{X} 1.1$ & 0,462 \\
\cline { 2 - 3 }$(\mathrm{X} 1)$ & $\mathrm{X} 1.2$ & .453 \\
\cline { 2 - 3 } & $\mathrm{X} 1.3$ & 0,625 \\
\cline { 2 - 3 } & $\mathrm{X} 1.4$ & .784 \\
\cline { 2 - 3 } & $\mathrm{X} 1.5$ & .766 \\
\cline { 2 - 3 } & $\mathrm{X} 1.6$ & 0,404 \\
\hline Training (X2) & $\mathrm{X} 2.1$ & 0.537 \\
\cline { 2 - 3 } & $\mathrm{X} 2.2$ & .834 \\
\cline { 2 - 3 } & $\mathrm{X} 2.3$ & .551 \\
\cline { 2 - 3 } & $\mathrm{X} 2.4$ & 0.477 \\
\cline { 2 - 3 } & $\mathrm{X} 2.5$ & .970 \\
\hline Competence (X3) & $\mathrm{X} 3.1$ & 0.672 \\
\cline { 2 - 3 } & $\mathrm{X} 3.2$ & .818 \\
\cline { 2 - 3 } & $\mathrm{X} 3.3$ & .718 \\
\cline { 2 - 3 } & $\mathrm{X} 3.4$ & .798 \\
\hline
\end{tabular}




\begin{tabular}{|l|c|c|}
\hline \multirow{4}{*}{ Job Satisfaction (X4) } & $\mathrm{X} 3.5$ & 0,794 \\
\cline { 2 - 3 } & $\mathrm{X} 3.6$ & .716 \\
\cline { 2 - 3 } & $\mathrm{X} 4.1$ & 0,711 \\
\cline { 2 - 3 } & $\mathrm{X} 4.2$ & 0.695 \\
\cline { 2 - 3 } & $\mathrm{X} 4.3$ & .783 \\
\cline { 2 - 3 } & $\mathrm{X} 4.4$ & 0.761 \\
\cline { 2 - 3 } & $\mathrm{X} 4.5$ & 0.665 \\
\cline { 2 - 3 } (Y) & $\mathrm{X} 4.6$ & .680 \\
\hline \multirow{4}{*}{ Employee Performance } & $\mathrm{Y} .1$ & .409 \\
\cline { 2 - 3 } & $\mathrm{Y} .2$ & 0.533 \\
\cline { 2 - 3 } & $\mathrm{Y} .3$ & 0,692 \\
\cline { 2 - 3 } & $\mathrm{Y} .4$ & 0.617 \\
\cline { 2 - 3 } & $\mathrm{Y} .5$ & .642 \\
\cline { 2 - 3 } & $\mathrm{Y} .6$ & 0.662 \\
\hline
\end{tabular}

Based on SMC value obtained almost all the variables reaches a value> 0.5 even though there are 5 items that are still below 0.5 but still close to the value of 0.5 that is retained to not drop in this study. Thus, all the indicators stated reliably.

\subsubsection{Evaluation of Goodness of Fit}

The results of the model fit tests using chi-square, CMIN / DF, CFI, TLI, GFI, and RMSEA as follows.

Table 5. Fit Model Struktural Early

\begin{tabular}{|l|c|c|c|}
\hline \multicolumn{1}{|c|}{ Index } & $\begin{array}{c}\text { Cut-off } \\
\text { Value }\end{array}$ & Result & $\begin{array}{c}\text { Evaluation } \\
\text { Model }\end{array}$ \\
\hline Chi-square & & 1126.623 & Well \\
\hline probability & $\leq 0.05$ & 0,000 & Not good \\
\hline $\begin{array}{l}\text { CMIN / } \\
\text { DF }\end{array}$ & $\leq 2.00$ & 3,053 & Not good \\
\hline GFI & $\geq 0.90$ & 0.611 & Marginal \\
\hline CFI & $\geq 0.90$ & 0,806 & Not good \\
\hline TLI & $\geq 0.90$ & .786 & Not good \\
\hline RMSEA & $\leq 0.08$ & 0.126 & Not good \\
\hline
\end{tabular}

Table 6. Fit Model Structural Repairs

\begin{tabular}{|l|c|c|c|}
\hline \multicolumn{1}{|c|}{ Index } & $\begin{array}{c}\text { Cut-off } \\
\text { Value }\end{array}$ & Result & $\begin{array}{c}\text { Evaluation } \\
\text { Model }\end{array}$ \\
\hline Chi-square & & 343.761 & Well \\
\hline probability & $\leq 0.05$ & .227 & Well \\
\hline $\begin{array}{l}\text { CMIN / } \\
\text { DF }\end{array}$ & $\leq 2.00$ & 1,058 & Well \\
\hline GFI & $\geq 0.90$ & 0.861 & Marginal \\
\hline CFI & $\geq 0.90$ & 0.995 & Well \\
\hline TLI & $\geq 0.90$ & .994 & Well \\
\hline RMSEA & $\leq 0.08$ & 0,021 & Well \\
\hline
\end{tabular}


Results of testing the full model in Table 5 and 6 is the result of the initial goodness of fit test and repair. Model improved after modification melakaukan indices. Chi square probability value experience perbaiakn of $\mathrm{P}(0,000)$ to $\mathrm{P}(0.227)$.

Chi-square value improved from 1126.623 became 343.761. Value CMIN / DF of 3,053 into 1,058. Value CMIN / DF <2. CFI value of 0,990 which is still above 0.90. RMSEA value of 0.126 becomes 0.021 which is still below the value of 0.08 . CFI value improved from 0,806 be 0.995 . GFI value improved from 0.611 into 0.861 , GFI criteria still in good category for approaching 0.90 . TLI value improved from 0.786 into 0.994 . Based on testing full model showed that the overall model improvements meet the criteria of the model fit. Full equation model of this study are presented in Figure 2 below.

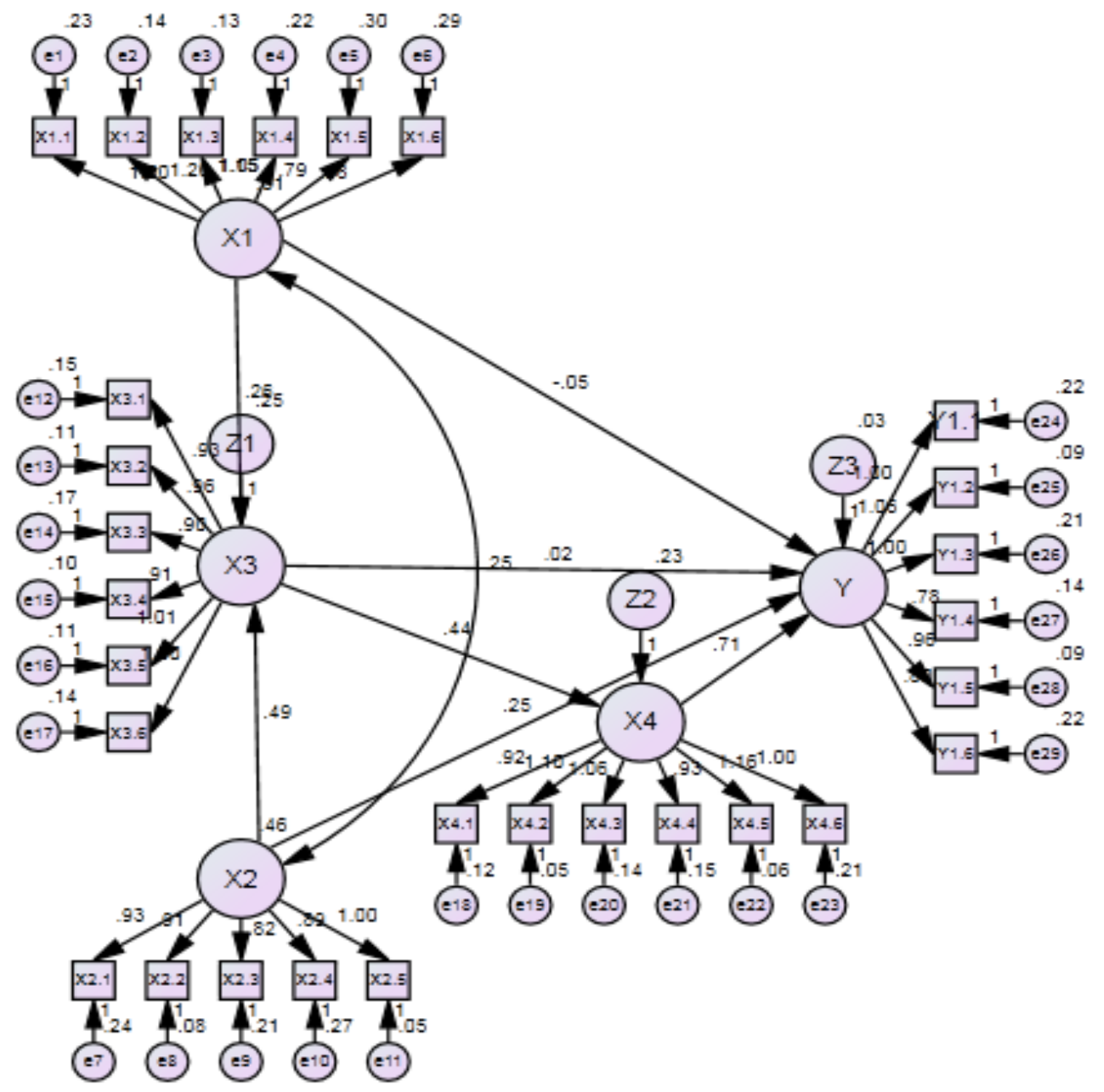

Fig. 2. Full Model

\subsubsection{Research Hypothesis Testing}

Results of the calculations through AMOS result of regression weights between variables (estimated loading factor), standard value error (SE), the value of the $\mathrm{t}(\mathrm{CR})$, and the probability values as follows.

Table 7. Structural Model Parameter Estimation

\begin{tabular}{|l|l|l|r|r|r|r|}
\hline \multicolumn{2}{|l|}{} & \multicolumn{1}{|c|}{ Estimate } & \multicolumn{1}{c|}{ S.E. } & \multicolumn{1}{c|}{ C.R. } & \multicolumn{1}{c|}{ P } \\
\hline X3 & $<---$ & X1 & .216 & .096 & 2.260 & .024 \\
X3 & $<---$ & X2 & .453 & .076 & 5.960 & $* * *$ \\
X4 & $<---$ & X3 & 1.076 & .179 & 6.010 & $* * *$ \\
\hline
\end{tabular}




\begin{tabular}{|l|l|l|r|r|r|r|}
$\mathrm{Y}$ & $<---$ & $\mathrm{X} 3$ & .023 & .052 & .440 & .660 \\
$\mathrm{Y}$ & $<---$ & $\mathrm{X} 4$ & .684 & .088 & 7.759 & $* * *$ \\
$\mathrm{Y}$ & $<---$ & $\mathrm{X} 1$ & -.026 & .069 & -.382 & .702 \\
$\mathrm{Y}$ & $<---$ & $\mathrm{X} 2$ & .238 & .062 & 3.863 & $* * *$ \\
\hline
\end{tabular}

Table 8. Hypothesis Testing Results

\begin{tabular}{|c|c|c|c|c|}
\hline Hypothesis & $\begin{array}{c}\text { Estima } \\
\text { te }\end{array}$ & $\mathbf{P}$ & Information & $\begin{array}{l}\text { Hypothesis } \\
\text { Test } \\
\text { Results }\end{array}$ \\
\hline $\begin{array}{l}\text { There is a positive } \\
\text { influence on learning to } \\
\text { competence of employees. }\end{array}$ & .216 & 0,024 & Significant & $\begin{array}{l}\text { Hypothesis } \\
1 \text { received }\end{array}$ \\
\hline $\begin{array}{l}\text { There is a positive effect } \\
\text { of training on employee } \\
\text { competency. }\end{array}$ & .453 & $* * *$ & Significant & $\begin{array}{l}\text { Hypothesis } \\
2 \text { received }\end{array}$ \\
\hline $\begin{array}{ll}\text { There } & \text { competence } \\
\text { influence } & \text { on job } \\
\text { satisfaction. } & \end{array}$ & 1,076 & $* * *$ & Significant & $\begin{array}{l}\text { Hypothesis } \\
3 \text { accepted }\end{array}$ \\
\hline $\begin{array}{l}\text { There is a positive } \\
\text { influence on employee } \\
\text { performance } \\
\text { organization. }\end{array}$ & -0.026 & $* * *$ & Significant & $\begin{array}{l}\text { Hypothesis } \\
4 \text { is } \\
\text { accepted }\end{array}$ \\
\hline $\begin{array}{l}\text { There is a positive effect } \\
\text { of training on employee } \\
\text { performance. }\end{array}$ & 0.238 & .660 & $\begin{array}{l}\text { Not } \\
\text { significant }\end{array}$ & $\begin{array}{l}\text { Hypothesis } \\
5 \text { is } \\
\text { rejected }\end{array}$ \\
\hline $\begin{array}{l}\text { There is a positive } \\
\text { influence on the } \\
\text { performance of the } \\
\text { employee competence. }\end{array}$ & 0,023 & 0,702 & $\begin{array}{l}\text { Not } \\
\text { significant }\end{array}$ & $\begin{array}{l}\text { Hypothesis } \\
6 \text { rejected }\end{array}$ \\
\hline $\begin{array}{l}\text { There is a positive effect } \\
\text { of job satisfaction on } \\
\text { employee performance. }\end{array}$ & .684 & $* * *$ & Significant & $\begin{array}{l}\text { Hypothesis } \\
7 \text { is } \\
\text { received }\end{array}$ \\
\hline
\end{tabular}

Description: $* * *$ (sigifikance $<0.001)$

\subsection{Discussion}

Based on the results of Table 8 obtained structural model parameter estimation is the estimated value of learning organization structural loading on the competence of 0.216 with a probability value of 0.024 is smaller than the critical value of 0.05 so that it can be stated that the regression coefficient, which measures the effect of a learning organization to competence was significant. The estimated value loading showed that the positive effect on learning organization competence. Thus, the first hypothesis stating that there is a positive effect on employee competency acceptable learning. The findings of this study support Tanriverdi and Zehir (2006) states that affect the learning organization competence. Learning organization is an organization that does a change in mental models to generate learning skills through a healthy mind, the ability to read a comprehensive model, understand interdependence, the ability to create a shared vision, and have the knowledge and capacity of 
others to share in understanding the technological innovation and the economy. Reinforced by Suzan and Marjulin (2016) which states that the learning organization is an organization that creates an atmosphere that supports and provides the widest opportunities for individuals in it to learn individually and in groups, and to apply the results of research into the processes and activities of the organization. Learning Organization produces competence is a primary characteristic of the individual. Competence is the result of merging the activities of individual resources: knowledge, ability, quality, experience, cognitive capacities, emotional resources to environmental resources: technology, databases, books, network connections, and others. Successful learning organization impact on organizational competence which is a behavioral approach to emotional intelligence, social intelligence and cognitive intelligence.

Based on the results of Table 8 obtained structural model parameter estimation is the estimated value of training to the competence of structural loading of 0.453 with a probability value of $* * *<$ smaller than the critical value of 0.05 so that it can be stated that the regression coefficient, which measures the effect of training on competency was significant, The estimated value loading showed that the positive effect on competency training. Thus, the second hypothesis which states that there is a positive effect on the competence of employees received training. This finding is supported by Robert (2006), that an effective training program helps employees to become acquainted with new technological advances that encourage increased competence and skills required to perform certain jobs and reduce the error rate in completing the work. The technological advances that encourage the banking sector must be prepared to face the challenge. According to Wei-Tai (2006), that advances in technology have established the need the ability and competence of employees needed to perform certain tasks. Through the training program, the employee can meet the challenge to support improved performance. Thus in the face of overcoming these challenges requires better training programs and effective by all companies. Effective training programs to help build a more conducive learning environment for the workforce and train them to face the challenges more easily and on time. Therefore, managers should try its best to support the training of employees so as to have a reliable competence. Farooq and Khan (2011) stating that the manager tried their level best to develop the skills of employees, ultimately creating a good working environment within the organization. For the sake of increasing the capacity of managers involved in developing effective training programs for their employees to equip them with the knowledge, skills and abilities desired to achieve organizational goals. Through training encourages skills and abilities into forming competence. managers must try our best to support the training of employees so as to have a reliable competence.

Based on the results of Table 8 obtained structural model parameter estimation is the estimated value of the loading of structural competence to the job satisfaction of 1.076 with a probability value of $* * *$ <smaller than the critical value of 0.05 so that it can be stated that the regression coefficient, which measures competency influence on employee performance was significant. The estimated value of loading showing that competence positive effect on job satisfaction. Thus, the third hypothesis which states that there is a positive influence on employee performance acceptable competence. This finding is supported by research Margono, et al. (2017) stating that the competence positive effect on job satisfaction. Supported by the findings Syahrum, et al. (2016) that the competencies and significant positive effect on job satisfaction. Linkage competence and job satisfaction described by Champathes (2006) that more and more employees are being developed can certainly improve the competence increasingly creating a level of satisfaction with their work, thus increasing the company's productivity and profitability. Jeon, et al. (2014) states that the three predictor variables were 
positively associated employee competencies and job satisfaction. One predictor of competence is through training programs that help labor to reduce the anxiety that comes from a job in the workplace [22]. The greater the gap between the skills of the workforce, the higher the dissatisfaction of workers [23]. Thus, the better the competency can increase employee job satisfaction. that more and more employees are being developed can certainly improve the competence increasingly creating a level of satisfaction with their work, thus increasing the company's productivity and profitability.

Based on the results of Table 8 obtained structural model parameter estimation is the estimated value of learning organization structural loading on the performance of employees is 0.026 with a probability value of 0,702 is greater than the critical value of 0.05 so that it can be stated that the regression coefficient learning organization that measures influence on employee performance otherwise insignificant. Thus, hypothesis 4 which states that there is a positive influence on employee performance learning organization rejected. This study is not in line with the research Mbuthia (2018) stating that the dimensions of the learning organization has a significant impact on the performance of the organization in the banking sector.

Based on the results of Table 8 obtained structural model parameter estimation is the estimated value of training structural loading on the performance of employees is 0.238 with a probability value of $* * *<$ smaller than the critical value of 0.05 so that it can be stated that the regression coefficient, which measures the effect of training on employee performance was significant. The estimated value loading showed that training has positive influence on employee performance. Thus, Hypothesis 5 which states that there is a positive influence on the performance of employees received training. Training has been done on the employee's fifth largest bank in Indonesia have an impact on employee performance. Training is given to the challenge of banking in the advancement of digital technology.
In line with the findings of Wei-Tai (2006) that global developments and technology that is fast, then the company today must face new changes as well as a great challenge. Elnaga and Imran (2013) explains that top management realized that the importance of investing in employee training and development for improving the performance of employees. Based on the review of the literature and some case studies on the importance of training to improve workforce performance by understanding the development of employees through training programs and its influence on employee performance. explains that top management realized that the importance of investing in employee training and development for improving the performance of employees. Based on the review of the literature and some case studies on the importance of training to improve workforce performance by understanding the development of employees through training programs and its influence on employee performance. explains that top management realized that the importance of investing in employee training and development for improving the performance of employees. Based on the review of the literature and some case studies on the importance of training to improve workforce performance by understanding the development of employees through training programs and its influence on employee performance.

Based on the results of Table 8 obtained structural model parameter estimation is the estimated value of structural loading competence on the performance of employees is 0,023 with a probability value of 0.660 is greater than the critical value of 0.05 so that it can be stated that the regression coefficient, which measures competency influence on employee performance otherwise insignificant, Thus, hypotheses 6 stating that there is a positive influence on employee performance declined competence. These findings are not consistent with research Zaim et al. (2013) that there is a positive relationship between competence and performance of individuals. Furthermore, the core competencies proved to have the most significant 
effect on the performance of the individual. The study provides some empirical evidence that refers to the individual's competence effects on organizational performance. These findings are also inconsistent with Jabbouri and Zahari (2014) that there is a significant correlation between core competencies and organizational performance. This finding is also not in line with research Martini et al. (2018) that the competence and positive effect on employee performance. Thus, this research see that competence has affected the performance of employees through job satisfaction. Competence positive relationships and job satisfaction as a signal of mediation. that competence and positive effect on employee performance.

Based on the results of Table 8 obtained structural model parameter estimation is the estimated value of structural loading job satisfaction on the performance of employees is 0.684 with a probability value of $* * *<$ smaller than the critical value of 0.05 so that it can be stated that the regression coefficient, which measures the effect of job satisfaction on the employee's performance was significant. The estimated value loading showed that job satisfaction has positive influence on employee performance. Thus, the hypothesis 7 which states that there is a positive influence on the performance of employee job satisfaction received. The findings of this study support Margono et al. (2017) that found job satisfaction has positive influence on employee performance. This finding also in line with Bhola (2015) who found that employee satisfaction is a critical success factor for all organizations. Companies must constantly satisfy the employees in order to remain profitable and meet company objectives. When someone claimed to have job satisfaction is high, it means that the employees loved her job.

\section{Conclusion and Recommendations}

\subsection{Conclusion}

Based on the discussion of the results obtained by some conclusions of the pilot testing of studies that have been carried out as follows:
There is a positive influence on learning and training to the competence of employees, there is the influence of competence against job satisfaction, a positive influence learning organization and job satisfaction on employee performance. This study can not prove the effect of training and competence on employee performance.

\subsection{Recomendations}

The findings that the training has positive influence on competence and competence influence on job satisfaction and job satisfaction a positive impact on performance. This indicates that the training programs given to employees with the right to increase the competence of employees so as to create job satisfaction of employees that have implications for enhancing the performance of employees. Some of the findings by 5 accepted hypothesis in this study indicate that the model in the research illustrates that programs of training and learning organization can improve the competence of either direct or indirect implications on the performance of employees. Their placement as an intermediary construct of job satisfaction increased competence on employee performance. Therefore, Thispenelian see that competence has affected the performance of employees through job satisfaction. Positive relationship competence and job satisfaction as a signal of mediation. Not influential learning organization should be observed that the banking sector also needs morerecognizes individual initiative of the organization to be directed to improve its performance. Things may be done by inviting employees to contribute to the organization's mission, encouraging, and equitable distribution of responsibility.

\section{References}

[1] S. Alainati, S. N. Al-Shawi, and W. AlKaraghouli, "The Effect of Education and Training on Competency," in European and Mediterranian Conference on Information Systems, 2010, pp. 1-9. 
[2] L. Suzan and Marjulin, "Learning Organization and the Impact on Competence in Organizations," in EProceeding of The 4th International Seminar and Conference on Learning Organizations, 2016, pp. 334-340.

[3] S. K. Nzioka, "The Relationship Between Organisational Learning and Performance Imrovement in Kenya's Commercial Banks," University of Nairobi, Nairobi, 2012.

[4] W. A. Nafei, "Organizational Learning and Organizational Performance: A Correlation Study in the Kingdom of Saudi Arabia," Am. Int. J. Soc. Sci., vol. 4, no. 2, pp. 191-208, 2015.

[5] A. Elnaga and A. Imran, "The Effect of Training on Employee Performance," Eur. J. Bus. Manag., vol. 5, no. 4, pp. 137-147, 2013.

[6] K. Margono, J. Munandar, and P. Muljono, "Analysis of Factors Influencing Performance Staff at the General Affairs Bureau of the Ministry of Marine Affairs and Fisheries,” Int. J. Bus. Manag., 2017.

[7] A. Bhola, "Job Satisfaction among Bank Employees: A Study On District Kathua (Jammu \& Kashmir)," Int. J. Manag. Commer. Innov., vol. 3, no. 1, pp. 186191, 2015.

[8] K. Sendawula, S. Nakyejwe Kimuli, J. Bananuka, and G. Najjemba Muganga, "Training, Employee Engagement and Employee Performance: Evidence from Uganda's Health Sector," Cogent Bus. Manag., vol. 5, no. 1, pp. 1-12, 2018.

[9] N. Venkatraman and V. Ramanujam, "Measurement of Business Economic Performance: An Examination of Method Convergence," J. Manag. Dev., vol. 13, no. 1, pp. 109-122, 1986.

[10] I. Muda, A. Rafiki, and M. R. Harahap, "Factors Influencing Employees' Performance: A Study on the Islamic Banks in Indonesia," Int. J. Bus. Soc. Sience, vol. 5, no. 2, pp. 73-80, 2014.
[11] H. Zaim, M. F. Yaşar, and Ö. F. Ünal, "Analyzing the Effects of Individual Competencies on Performance: a Field Study in Services Industries in Turkey," J. Glob. Strateg. Manag., vol. 2, no. 7, 2013.

[12] A. B. Escrig-Tena and J. C. Bou-Llusar, "A model for evaluating Organizational Competencies: An Application in the Context of a Quality Management Initiative," Decis. Sci., vol. 36, no. 2, pp. 221-258, 2005.

[13] S. El-Sabaa, "The Skills and Career Path of an Effective Project Manager," Int. J. Proj. Manag., vol. 19, no. 1, pp. 1-7, 2001.

[14] D. S. Chiaburu and A. G. Tekleab, "Individual And Contextual Influences on Multiple Dimensions of Training Effectiveness,” J. Eur. Ind. Train., vol. 29, no. 08, pp. 604-626, 2005.

[15] P. Tharenou, A. M. Saks, and C. Moore, "A Review and Critique of Research on Training and Organization Level Outcomes," Hum. Resour. Manag. Rev., vol. 17, no. September, pp. 251-273, 2007.

[16] J. Shen and R. Darby, "Training and Management Development inChinese Multinational Enterprises," Empl. Relations, vol. 28, no. 4, pp. 342-362, 2006.

[17] P. M. Senge, The Fifth Discipline: The Art and Practice of the Learning Organization, Revised an. New York: Doubleday, 2006.

[18] Kreitner, Leadership for Improving Productivity of Schools. New York: John Wiley \& Sons, 2006.

[19] H. Tanriverdi and C. Zehir, "Impact of Learning Organizations Applications and Market Dynamism on Organizations' Innovativeness and Market Performance," Bus. Rev., vol. 6, no. 2, pp. 238-245, 2006.

[20] M. Farooq and M. A. Khan, "Impact of Training and Feedback on Employee Performance," Far East J. Psychol. Bus., vol. 5, no. 2, pp. 23-33, 2011. 
[21] J. R. Jeon, A. Lee, and N. Chen, "Effect of Competency at Work on Job Satisfaction and Organizational Commitment in The Restaurant Industry," in 13th Asia Pacific Forum for Graduate Students Research in Tourism, 2014, no. May, pp. 11-17.

[22] T. Y. Chen, P. L. Chang, and C. W. Yeh, "A study of Career Needs, Career Development Programs, Job Satisfaction and the Turnover Intensity of $\mathrm{R} \& \mathrm{D}$ Personnel," Career Dev. Int., vol. 9, no. 4, pp. 424-437, 2004.

[23] R. W. Rowden, "The Relationship Between Workplace Learning and Job Satisfaction in U.S. Small to Midsize Business," Hum. Resour. Dev. Q., vol. 13, no. 4, pp. 407-425, 2002.

[24] A. Syahrum, I. A. Brahmasari, and R. Nugroho, "Effect of Competence, Organizational Culture and Climate of Organization to the Organizational Commitment, Job Satisfaction and the Performance of Employees in the Scope of Makassar City Government," Int. J. Bus. Manag. Invent., vol. 5, no. 4, pp. 52-64, 2016.

[25] R. N. Mbuthia, "Learning Organization Dimensions and Organizzational Performance of Commercial Banks in Kenya: Survey of Commerial Banks in Ongata Rongai Township," School of Business, Kenyatta University, Nairobi, 2018.

[26] A. Khandekar and A. Sharma, "Organizational Learning and Performance: Understanding Indian Scenario in Present Global Context," Educ. Train., vol. 48, no. 8-9, pp. 682692, 2006.

[27] N. I. Jabbouri and I. Zahari, "The Role of Core Competencies on Organizational Performance: an Empirical Study in the Iraqi Private Banking Sector," Eur. Scietific J., vol. 1, no. June, pp. 130-139, 2014.
[28] I. A. O. Martini, I. K. Rahyuda, D. K. Sintaasih, and P. S. Piartrini, "The Influence of Competency on Employee Performance through Organizational Commitment Dimension," IOSR J. Bus. Manag., vol. 20, no. 2, pp. 29-37, 2018.

[29] J. F. Hair, W. C. Black, B. J. Babin, and R. E. Anderson, Multivariate: Data Analysis, 7th Edition. New Jersey: Pearson Prentice Hall, 2010.

[30] V. J. Marsick and K. E. Watkins, "Demonstrating The Value of An Organization's Learning Culture: The Dimensions of Learning Organizations Questionnaire," Adv. Dev. Hum. Resour., vol. 5, no. 2, 2003.

[31] A. Sultana, S. Irum, K. Ahmed, and Nasir Mehmood, "Impact of training on employee performance:A study of telecommunication sector in Pakistan," Interdiscip. J. Contemp. Res. Bus., vol. 4, no. 6, pp. 646-661, 2012.

[32] C. L. Ubeda, F. C. A. Santos, and M. S. Nagano, "Analysis of the Individual competences contributions to innovation Management Based on Methodological Triangulation," Gest. e Prod., vol. 24, no. 3, pp. 595-609, 2017.

[33] O. Basol, "Classic or Modern?: Enhancement of Job Satisfaction Scale for Green Job Workers," Management, vol. 11, no. 2, pp. 103-122, 2016.

[34] H. C. Wang, "A Study on the Relationships among Knowledge Management , Situational Factors , Professionals ' Core Competencies and Job Performance - Taking the Vocational Training Centers and Employment Service Centers as Example Job performance," J. Hum. Resour. Adult Learn., vol. 3, no. 2, pp. 117-127, 2007.

[35] H. Aima, R. Adam, and H. Ali, "Model of Employee Performance: Competence Analysis and Motivation (Case Study at PT Bank Bukopin, Tbk Center)," J. Res. 
Bus. Manag., vol. 4, no. 11, pp. 49-59, 2017.

[36] W. T. Wei-Tai, "Effects of Training Framing, General Self-efficacy and Training Motivation on Trainees," Train. Eff., vol. 35, no. 1, pp. 51-65, 2006.

[37] M. R. Champathes, "Coaching for Performance Improvement: The Coach Model," Dev. Learn. Organziazations, vol. 20, no. 2, pp. 1-17, 2006.

[38] A.Kapoor, S. Dubey, (2016) Impact of Adhd On Motivation Scores In An Educational Organization, International Journal Of Organizational Behaviour \& Management Perspectives (C) Pezzottaite Journalsvolume 5, Number 3 ISSN (Print): 2279-0950, (Online): 2279-0969 